Lulla S. Johns

\title{
22 Miles Home
}

IT IS THE FIRST OF SEPTEMBER AND TIME TO RETURN TO RESIDENTIAL school. If I just, just keep pushing down the fear and don't think of the day I have to leave-who knows? - maybe something magical will happen and I'll get to stay with my mother. I love the fall despite the dread of returning to school. The north wind stirs up feelings of anticipation about walking to new lands in this boreal forest here on the Alaska-Yukon border. Large flocks of swans, sandhill cranes, and geese call to me as they fly over on their way south. I am nine and determined to hide again from the priest who picks us up every year from our summer camp along the Alaska Highway.

After leaving our camp, we would have a five-hour drive on the rock-filled Alaska Highway back to the village of Burwash, 100 miles away. After overnighting in Burwash we would board a bus the next day with more kids from that village, then overnight in Whitehorse 200 miles away. The next day would be another long 300 miles before we reached the residential school in Northern British Columbia. Altogether I would be 600 miles from my home and as young as I was, I knew it was too far to run away from school. 
Therefore, it seemed to make perfect sense to not be picked up in the first place. It was best to avoid the whole dreadful situation and maybe Mom could find a way to keep me. Maybe the priest and the authorities would just give up because I was so clever at avoiding them. Surely that could happen? After all, I was just one kid. Why would they worry about just one kid when they had so many others from my family and other villages? Maybe the road would wash out or Father M would run off the road and die in a car accident. Then the secret would die with him and no one, not even the RCMP, could get me, because no one would know I was alive! I was so happy thinking these thoughts. I nursed the hope that it would all just pass over me, just fade away and I could stay on the American side of the border. Then I could go to school in Northway on the American side, or 22 miles east in Beaver Creek on the Canadian side. Nursing these thoughts I steel myself to run away again when the priest comes to take us back to school.

There were just four tents set up at our summer camp near the Alaska Highway: my mother's, my grandparents', and those of my mother's sister who had six children and my mother's brother. Despite being camped several miles on the American side, the priest, instructed by the church to collect as many Indigenous children as possible for the schools, would drive over to get us. With no US customs office set up in the 1960s, he would drive across the boundary line and pick us up with no one being the wiser.

And today that priest is walking down the trail towards our camp. I feel sick and see him as in a dream. The hazy morning mist rises up behind him, framing his black figure. Time stops. The sky is so blue and stays blue to the horizon, the dogs are quiet and only the gray jay scolds the intruder. My family is utterly quiet. Even the younger children stand still and watch mesmerized as the black and white figure comes toward our haven. My grandfather speaks first. In our language he says "He is coming," and I hear the breath whoosh out of my chest. Father M greets the adults and after some talk on the weather and trapping prices he asks if the kids are ready to go. With downcast eyes and heavy hearts we walk single file down the trail. Our parents and grandfather follow. 
It's now or never. I dart off the trail when we round a corner and no one behind sees me going off trail and no one walking in front knows I've gone. I'm that silent on the moss. I lie behind a large soapberry bush and curl up so my feet won't show. I watch my mother, my aunt, and my grandfather go by carrying cookies, candy, and pop for our snacks along the drive. My cousin Peter, who turned sixteen this year and quit school as soon as he was legally allowed, comes striding down the trail later, a worried look in his eyes. He seems tall because he is so skinny, and he has large eyes and a head topped with a thatch of jet black hair. He is considered handsome by many girls and we younger ones imitate these girls as often as possible to tease him. Peter cannot bear to see his siblings go back to that school but he cannot bear not seeing them off either. He is too preoccupied to see me. My chest is getting tight from holding my breath all of this time. Once Peter passes I get up slowly and peek down the trail and toward the priest's car parked up on the gravel road. The road is much higher than the muskeg and I realize the priest or someone will spot me soon by looking down into the stunted spruce trees. I start crawling on my hands and knees being careful not to move branches. There are larger trees next to the muskeg where it is dark and cool and many windfalls behind which I can hide.

Soon I hear people calling my name. The priest calls out my name, then my mother calls. Everyone calls me now but I do not answer. My heart is beating so loud I can hear it. I know what happens when you disobey the priests and nuns. You get a good beating and then you are publicly berated and humiliated in front of the whole school. But that isn't going to happen because they will not catch me. Perhaps I will starve out here, maybe even die. Then what will they think? They will be so sorry they forced me to go to school. Everyone will feel so bad that they did this to me. I feel some satisfaction at having so many people feel badly about how they've treated me. They keep calling me. If I stay put I can dare myself to stay longer and not respond like I usually do. My mother and cousin Peter walk up and down the trail calling out to me; telling me if I don't come there will be trouble. Soon I hear the station wagon pull away and I know the priest has left with my cousins. 
With my heart thudding I walk back into our camp before my mother gets there. I have no idea of the threats the priest has made to my Mom. Like that she may lose her child allowance or that she could go to jail. That monthly allowance was sometimes all the money they had to buy groceries from the store if the trapping was poor. I never learned till years later that the government would've withheld the children's monthly allowance or would've taken her to jail for not sending me to residential school.

For now, I'm overjoyed at eluding the priest and rush into the tent to see my little sister lying asleep next to my grandmother. Sister will keep my mother occupied if I'm in residential school and lessen the hurt of me being gone for ten months. I rush into my auntie's tent and see her two little ones playing. Both are under six years old. I am so happy and I have the whole camp to myself! But slowly, slowly as I wander about the camp it becomes lonely without the other children. I wait apprehensively for my family to return from the road while alternately trying to feel defiant.

I know whoever controls this school situation will be upset but I still do not understand why I have to go so far to school. Why can't Mom speak up against this? Why can't the parents of my cousins speak up and say no; that we can go to school in Northway on the American side or even in Beaver Creek on the Canadian side? What do they fear? I wonder at the power of those other people.

I know Mom will not be too angry when she returns from the road. When she does return she looks at me and says "Gee wess, you gotta go school. Mommy get in trouble if you doan go school. Govment say so. You gotta go school. Father say you gotta ketch next bus in two week. Go Beaver Creek and wait at Grandma E's. You ketch bus from there and go school." I am so happy all the while trying to look contrite. I'm so relieved and happy; two weeks of freedom and being with my family! The sky is so blue, the songs of birds so clear, and even the steady drone of mosquitoes is comforting.

I spend the next two weeks awakening each day in disbelief that I'm still with my family. But in the next minute I feel dread with the realization that it will all end soon. Each day is an unrelenting marker to when I will have to go away from my family for ten long months. When I think like this my chest starts to feel empty and hollow so I 
keep busy playing with the little ones and helping with chores. As I pack water and wood the smells of the dying summer tantalize my nose. The ground is pungent with rotting leaves and dried berries. The trees prepare for winter's sleep as the golden aspen and birch leaves twirl and dance through the air. I feel the bite in the air from the north wind, the emptiness of the forest as birds continue south. However, the call of the sandhill cranes becomes even lonelier when my mother and grandmother stand and sing to them their songs of goodbye as they fly overhead. Flocks of geese and tundra swans fly over in large $\mathrm{V}$ formations and it now makes me so very sad. Every once in a while, I catch my mother watching me with sympathy in her eyes and I note the extra care and attention my family gives me as I wander the camp alone.

The day arrives when I have to go to Beaver Creek to meet the priest. He will arrive the following day to drive me 100 miles to Burwash Landing to be put on a bus for my journey to the residential school. Beaver Creek is 22 miles from the American border and is a Canada border stop. We lived 22 miles west of the Canada Customs or two miles inside the American border. My mother instructs my cousin Peter to hitchhike to the community and to leave me with my grandmother's sister.

It is mid-morning; I dress slowly to make the time stretch out. I wear my new T-shirt, coat, pants, and deck shoes. The shoes are made of soft, thin rubber. Mom has no money to give me this year but I know she will send some later to the school. She always does. I have no idea how difficult this is for her because every bit of trapping money was needed for groceries and other necessities. All morning I've watched while she curls her hair and readies clean clothes for a trip she will be taking to the American side. She is beautiful; tall, well-built with beautiful eyes and a straight nose. She carries herself proudly befitting her status as the daughter of a Chief. I don't want to think of her going away from my grandmother and sister but she seems driven to leave. My father left a couple of years ago and she must find another partner.

After breakfast Peter and I walk that suddenly-short trail to the road to hitch a ride. I cannot bear to leave my grandmother. She tells me not to cry, that I have to go to school to learn things. I look at my little sister. She will be bigger when I return but I cannot know how 
big as I won't be here to watch her grow. My grandfather looks stern. He says I have to go quickly to get a ride before dark. All the traffic is heading south from Alaska. Someone will stop for us. My uncle, small, lean, and wiry, pretends to be busy chopping wood. He looks at me quickly and then away. "Go to school," he says. "Learn White man way and you can help us." I don't understand this and believe he is just saying something to cover the awkwardness and sadness of the situation. Peter is officious for being sixteen. He is anxious about his task and worried about getting back to our camp in the same day. On the trail he tells me to hurry up.

My mother's cousins arrive from Northway, a larger village on the American side. They will take Mom to their village to attend a potlatch for someone who has passed away. I know they will also go on a party after and Mom will drown her sorrow in alcohol. She leaves quickly and I see the sadness and concern alternate with suppressed rage. She says "Don cry. Mommy be here when you come back. Grandma don like it when you sad so be a big girl and go with Peter. You gotta learn read and write." She leaves in her cousin's car toward Alaska while Peter and I stand forlornly on the road. The first car drives by us. I am apprehensive about getting a ride while at the same time I'm hoping no one will give us a ride. The next vehicle is a big truck but it cannot take the both of us. The third vehicle stops and we explain our situation. Peter is carrying a 22-calibre gun for protection for when he walks back to our camp alone. The driver invites us into the car and chats with Peter about why we are hitchhiking and then about the weather. He's fascinated to hear that we've lived through 50 degrees below zero.

I sit silently watching my "kaye," my land that I live on, go by. The gravel road kicks up a fine dust behind us and several times we slide around corners on the loose gravel. We reach Beaver Creek midmorning and get off at Grandmother's sister's place. Peter explains the situation - that she must keep me for the night and the priest will come the next day to get me. The priest is likely ticked off about having to come this distance again when I should've been on his first trip to get us. While she feeds us, Grandma's sister, whom I also call Grandma, asks for news on every member of the family. I'm sure I can't eat but the moose meat stew is delicious and I eat my bowl of it. I try to eat the bannock bread but I'm too full. 
All too soon Peter says he's ready to go and I involuntarily cry out "No!" He looks at me sternly. We are not supposed to express our disagreements when visiting other people. He says "No, you stay here and wait for the priest or your Mom will be in trouble." He shoulders the gun and says "I have to go or it will be dark before I get a ride." I follow him out the door as he says good-bye to Grandma E.

But now the fear of not seeing my mother again or the possibility of her not coming back from her trip become too great. My mind is alive with all the possibilities that could go wrong including what may happen to my sister and Grandmother.

"Peter," I said "I want to go back with you." He frowns and emphatically says "No!" Then he says more gently "You can't come back," while at the same time I see the pity in his eyes. This spurs me to be brave. Perhaps he will relent and I can go back home; just go back.

I do not understand why I cannot just stay with my family and not go to school or at least go to school in Beaver Creek like Grandma's sister's kids. Grandma's sister is married to a Norwegian and the priest won't take kids whose white fathers are around. Peter starts walking up the driveway and I dart out after him. Grandma calls to him in our language. He turns menacingly. "Go back" he says waving his arms towards Grandma. "Go back, don't you understand you have to go to school? Father will be really mad at you." He says more gently "Just wait here till he comes," like it's not so bad to do that. "No," I say. "I want to go home."

Grandma tries to grab me but is not strong enough to hold me. I twist my arm out of hers and run after Peter again. He turns again and again to threaten me to go back to Grandma but I stay well out of reach. I'm athletic and a really fast runner. I gauge the distance I need to stay back so that he won't catch me even with his long legs. Finally, in desperation and concern with the lateness in time he ignores me and continues walking on the gravel road heading back to our home. I hear Grandma calling and calling me. "Don't go," she says, "stay with me." Peter says "I'm not paying any attention to you. I'm not going to be responsible for you. I did as your mother told me. It's going to get dark before I get a ride and I'm going to walk fast. If I leave you behind it's your fault. I'm not waiting for you. You're supposed to go back." 
I stay well back from him as we walk on the gravel road heading north. I'm wary that he'll suddenly change his mind, grab me, and take me back to Grandma E's house. The gravel is hard to walk on; I can feel it through my thin shoes. Soon we walk past the Canada Customs office going north and I hope no one will come out to ask why I'm out of school. Peter walks quickly, long legs pumping. He's worried about getting a ride before dark. It's the time of year when the bears are still fattening up before their winter sleep. I have to run sometimes to catch up to him. Soon the town is behind us. The forest is black and silent on both sides. In a couple of miles we will come upon open ground or muskeg. Once in a while a car or truck drives by heading south. No vehicle is going north this time of year. I'm hoping a Lynden Trucking rig will come by and give us a ride. Soon we've walked a couple of miles and finally Peter slows down to a regular walk. I look at the junk in the ditches as we walk. Different things tourists have thrown out before they get to Customs are strewn in the grass and mud. There are pop bottles, cans of beer, empty food boxes, and many candy wrappers. I sigh as I catch my second wind. I feel much more calm now that I know Peter won't bother with chasing me anymore. However, I am concerned about keeping up because he seemed serious when he said he'd leave me behind if I couldn't keep up. I hear a Canada gray jay calling inquiringly from the black spruce. Is he asking me why I'm not going back to school? Or is he asking me if I have food? Maybe he knows I do not belong there, on the land, at this point in time, and is asking why I'm there?

On and on we walk. I recognize the landscapes as they appear, landscapes which appeared so much more quickly when I rode by in a car. I hear a squirrel. The buzzing of its call reverberates in the still air. Another squirrel across the road answers it. The air is cool and the sky is clear and so blue. The silence is broken by the crunch of gravel under our feet. We walk and walk and soon we're out in the open muskeg area. This is where the grassy hummocks grow so closely together it is difficult to walk through. Each hummock is not quite large enough to plant the whole of your foot on, but they grow so closely together you must stay balanced on top of one or have your foot slide down into the surrounding watery mud. To make any time walking though these areas is a combination of jumping and balancing then quickly jumping 
again before you fall off. This is where the bog blueberries grow and where the moose like to travel. If you can't balance on the hummocks your shoe slides off the grassy heads into the muck, your shoe comes off, and it's a messy, muddy thing to put back on.

Every year when we return from school the adults laugh when we stumble and slide off the grassy heads, trying to re-learn how to walk the hummocks again. "Did you forget how to walk your country?" they tease us in our native language. We get shy when they tease us and we too laugh at ourselves as we quickly try to overcome our stumbling. But every summer we seem to forget something else about living off the land. Every year we seem to know less and less of our ways, and it feels like such a betrayal of our family and ways that we cannot walk the land as they did. I feel I am becoming different from my people when each year I understand less and less of the language. I overcome these fleeting worries by striving harder to balance and run on the grassy heads, and sometimes tentatively speak the language when my grandmother talks to me. But I am forgetting more and more and my pronunciation is not getting better.

I continue to watch the scenery and the ditches as we walk and walk. The sun is out and it is a beautiful day. After several hours I tell Peter I want a drink of water. We drink from a small creek and keep walking. Soon it is noon and I am getting very warm. In my eagerness to get away from Grandma E's I left my coat on her chair. A few mosquitoes buzz us now and then. The landscape changes again and now we are walking through rounded hills covered with black spruce. In about four hours it will be getting darker but I feel sure we will be home by then.

I see a pipeline running over a small hill and know it is a shorter way to go rather than staying on the windy road. "Peter, I say excitedly, "look at the pipeline. It's a short cut! Let's go that way." "No," he says, "can't you see all I have is a 22?" He sounds mad. He is worried about being on the road with just a small gun and me slowing him down too. It is his first time being at home full-time since he was six years old. He hadn't counted on being responsible for me. Likely he is thinking he would be home by now learning how to hunt and listening to our grandfather tell stories. "Come on," I say, "it's just a little hill. We could run over it." He gives me a disparaging look. "You think you can outrun 
a bear?" "Huh!" he grunts. I knew better than to push him so we keep walking. I can feel the rocks through my shoes and hope the shoes will hold out. Further down the road I ask him if he would pack me on his back. He doesn't answer; just keeps walking with his back to me. "You wanted to go home," he said. "You should've stayed."

On and on the road twists ahead of us; a chalky white gravel road through the black forest. Sometimes the road goes uphill, then around sharp corners or dipping into valleys of muskeg. The odd trembling aspen or birch dots the landscape with their few remaining leaves. The air is still and clear. Our ears strain to hear a car heading north.

Not one car passes us. Finally by mid-afternoon we come to a sign that says Little Scottie Creek. "Peter, Peter," I yell in delight. "We are so close. We're almost home," I say happily. He looks at me with pity. "We are not even close to home," he says. "It doesn't say Scottie Creek does it?! We live near Scottie Creek, not Little Scottie Creek," he growls. Then to further prove his point he says, "We're only halfway there." I am so disappointed. I feel crushed by the idea of walking the same distance as I've already done today.

The sun is now dipping behind some hills but will reappear once we get on flat land. The forest on either side is silent except for the occasional jay or squirrel. I give a deep sigh and push on. I have to blank out the distance in my mind and just look at the next stretch of road. Once I reach that point I look at the next stretch and just decide I will only walk that far. I am not going to show Peter any weakness now that I have come so far. We come from tough people. People who used to war with other tribes in the dead cold of winter; who could subsist on very little water and who could walk miles over the forest and muskeg. I am going home and I am determined to get there. Boy, won't Grandma and my baby sister be so surprised to see me! It will be such a surprise. And here they thought they wouldn't see me again for ten more months, but I will pop up just like that. I grin in anticipation.

On and on we walk. It is getting cooler now with the sun occasionally behind the hills. The bushes and plants along the road take on a strange gloaming. They look like they are soft and floating things not really rooted in the here and now; just things that would suddenly materialize into view. There are soft rustlings from the bushes beside the road. Sometimes there are sudden scurryings. I walk 
closer to Peter. There could be a "bush man" or a "stick injun" lurking in the tall grass waiting to steal me if I get too close. I walk closer to the centre of the road. I've heard of how you know they are around by their occasional whistles but mostly by the smell of them. I listen intently for whistles but the road distracts me. My feet are starting to hurt but I have to ignore them. It is cooler now but I do not feel the cold. My body is warm from walking so fast. On and on we go. I can see it is getting darker. I can't believe we've walked this far and no car has come along. I am breathing deeply as Peter keeps up a steady walk. Every once in a while his head jerks toward the bushes as if expecting something to rear up. He is frowning steadily now. I am increasingly wanting the country around my home to appear. Surely it will be up around the next hill ... maybe around this bend. Everything will fall into place once we could see the familiar hills around our camp and the fish creek where we set our nets in summer.

All I can hear is the crunch of gravel under our feet. My nose starts dripping in the cool evening air. I grab some grass and blow my nose. I can see Peter is not ever going to rest. I've asked him a couple of times to wait but he will not. We plod on as the hills around us get darker and darker. Some of the bushes on the side of the road now appear in shade while others pick up a little light, their last remaining leaves rustling in the cool air. We hear something squawk in the woods. "What was that, Peter?" I ask rushing up to him. "Just an owl caught something," he says. On and on, the road is never ending. When will I see those lovely familiar hills around Scottie Creek? If this lasts much longer we will not see them; it will be too dark. But we can't get lost can we? The road goes past our camp and if we only walk one direction it should be there, right?

It is now dark with just a little light left. I am getting very tired and sleepy. I catch myself falling asleep as I walk and awaken when I fall over to the side. The road winds on and on. Finally Peter says there's T'so Ghut Guy (small spruce tree) hill where we set our fish nets. I am overjoyed and know our fish camp is only a mile from home, but we have to reach the fish camp first. For now it remains far off in the distance appearing so elusive as we round corners and then we lose sight of it again. I try walking faster but can't. My body is getting tired. I feel a little more awake now that I know we are closer to home. 
I believe it is very close but we can only keep walking to find out. I realize I haven't peed the whole day and have barely drunk any water. I feel no desire to pee or drink more water. I am a robot that has no feelings; I just have to keep putting one foot down in front of the other; just keep moving.

Finally we reach the bottom of the hill which overlooks the old fish camp. Only another mile to go. The fish camp is right at the border at Mile 1223 on the Alaska Highway and I know this morning after we left, everyone has moved closer to the border to Mile 1224. This is where the head of the trail starts, which leads back to our winter cabins. My ankles feel funny but I ignore them. Now that we are so close to home I have to push on. Several stones have been working their way into the holes in my shoes. Having run around all summer without shoes my skin is hard and the rocks do not bother me so much except they throw off my stride. Soon we are on top of the hill of the fish camp and I can see down the road to where Tsul Maid Mun Lake is glistening under the stars with whatever faint light is left. The lake is directly across from our trail. The mist is rising from the lakes and creeks as they lose their warmth to the cool air. My arms feel cool but I feel so much better being so close to home. My feet feel sore but I have no time to look at them and no light with which to see. We walk steadily and that half mile is the longest of the day.

Finally we come to the marker for the trail and we slide down the embankment onto the muskeg trail. Our feet immediately hit cold water and my feet have never felt so good. I wonder why the water makes my feet feel so good. We slosh through the trail and I can hear the dogs barking as we walk the quarter mile trail to our new camp. Peter knows his way in the dark and I stay right behind him. The cold water is wonderful on my feet. Finally we get to camp but only Grandpa is up to see what the dogs are barking about. I crawl into Grandma's tent and pass out.

The next morning I awake about mid-morning. No one is in the tent. I can hear quiet voices by the campfire. I am so, so happy! I did it! I'd walked from Beaver Creek, all 22 miles in one day, and am now looking up at the roof of the tent all lit up from the sun. I quickly jump up and start running for the door only to find myself falling over on my face. I can't believe it. Normally so strong and such a good runner, 
what has happened to my ankles? I look down to the back of my ankles; both Achilles tendons have swollen so large the skin covering the tendons broke open when I tried to run. Despite this I crawl out on all fours, still happy, to the campfire. I expect praise and happiness from my grandparents. Instead they give me worried looks and check my feet. They continue talking quietly in our language as they feed me tea and fried fish. They are unsure now as to what to do. They know the priest will be coming back looking for me and maybe he'll even bring the Royal Canadian Mounted Police. My coming back has also thrown off their plans to move back to the winter grounds to get ready for the season. They will have to wait now for the priest to come and who knows when that might be. They will have to listen each day to hear if any car stops on the road, and listen intently because the road is a quarter mile away through the trees, shrubs, and muskeg. They will have to rely on the dogs to let them know someone is there, and then they will walk to the road to meet the priest to show him where the new camp is.

As I eat and listen to their talk a sudden quiet comes over them. Something serious is going on when the adults all stop talking at once. I look up from the campfire to where they are looking. There is a huge spruce tree right next to the fire and at the very top is a large golden eagle. No bird in the wild would ever land so close to where campfire smoke is rising and where people are moving about. The eagle is majestic and glints gold in the sun. It seems to look far into the distance, bobbing its head around, when suddenly it casts one eye sideways down to me. I am in awe. Everyone is quiet. I try to hold its glance but it seems too sacred and therefore impolite to do so. Suddenly it lifts off the tree and you can hear the beat of its wings moving the air, and just as suddenly the sight and sound of it disappears beyond the trees. Grandfather finally breaks the silence. He says it came for me to acknowledge the many miles I'd walked; that it would watch over me and bless me. This was a big sign from the animal world. I feel terribly shy and so very proud. I feel like one of the heroes in some of the books I've read at school. I feel special. A golden eagle has sought me out and was proud of me walking those many miles. The guilt I feel about holding the family back from the winter grounds lessens. 
The next day before noon the priest comes and honks from the road. Peter brings him to the camp and you can hear the priest muttering as he sloshes through the muddy trail to get me. I don't cry in front of my family but hot tears roll down my cheeks as I follow the priest back out to the road. The drive back to Burwash Landing on a sunny day is pure anguish. Every lake and creek sparkles in the clear air of September. The little waves look so dear and the shoreline so special with many dark, secret spaces that disappear into the forest. The grass around the lakes is a lovely, waving golden rim. I long to be there wading in the water looking for little fishes. Every piece of driftwood, every little ripple in the lake looks so familiar and dear. Off in the distance I can see the mountains got snow the night before. Could I really be leaving this land not to see it again for ten more months? I cry silently and face the side window so the priest will not see me cry. He smells of pipe smoke and continually prays in whispers, sometimes muttering aloud in a low voice.

I feel rage and anger rise up in me. I start to hate because I feel so powerless. I decide everyone is to blame, including my family. I simply do not know who to blame for my predicament. Most of all I hate society and its power over me. Sometimes I feel pity for my mother and I just cannot understand why such a strong woman has no say over where her children can go to school or why we are taken every year.

When I get to Whitehorse that evening there is a lady who used to go to the same residential school as me. She is older and left as soon as she was allowed. She is also waiting to take the same bus back to her village, about thirty-six miles from the residential school, a large village called Upper Liard. She looks at me with pity but I am still mad that night and determined not to cry. The next morning we get on the bus and she starts talking to me. I start to cry as we pull further away from the city, sobbing large gulping sobs. She takes me in her arms and talks kindly to me. The more kindness she shows the more heartbroken I feel. I finally fall asleep, exhausted from crying. When I awake I start crying again. It seems I cannot help myself. I cry and cry for most of that trip. Poor Mary, there is not much she can do except hold me. She feels so motherly to me. I have to stop crying when she gets off at her stop. She says, "Be good. Nothing you can do about this 
and the nuns will spank you if you keep crying so just think about all the school friends you'll see again. I'll try come and see you." She waves from the doorway of the bus. I nod to her; I know she won't visit me at the school but I do want to obey someone who has been so kind to me.

She gets me thinking about my friends and I wonder if everyone in my school grade has made it back to the residence. What will they think now that I am coming to school so late? I bet they'll think I am so brave. I expect a hero's welcome from the girls. But the bus has got in so late that only the older girls are up whispering amongst themselves as the nun shows me my bed. I am so tired by then I go right to sleep. In the morning, I greet my friends and blank out my feelings for the coming year. I am glad I ran away and feel my two weeks of freedom was worth all the trouble. Who knows, next year I might just try the same thing again.

This is intended for personal use only. Please do not further copy or reproduce this story without prior permission from the author who you may contact through review@yukoncollege.yk.ca. If you appreciated this story, please consider contacting the author to learn how you might offer support.

Thank you. 